Journal of Humanities and Social Sciences Studies (JHSSS)

ISSN: 2663-7197

DOI: 10.32996/jhsss

Journal Homepage: www.al-kindipublisher.com/index.php/jhsss

\title{
How Images of Young Women Facilitate the Narrative of Decolonization in Jan Lowe Shinebourne's The Last English Plantation
}

\author{
Abigail Persaud Cheddie 8(D) \\ Lecturer, Department of Language and Cultural Studies, University of Guyana, Georgetown, Guyana \\ $\triangle$ Corresponding Author: Abigail Persaud Cheddie, E-mail: abigail.cheddie@uog.edu.gy
}

\author{
ARTICLE INFORMATION \\ Received: August 10, 2021 \\ Accepted: August 22, 2021 \\ Volume: 3 \\ Issue: 8 \\ DOI: $10.32996 /$ jhsss.2021.3.8.2
}

\section{KEYWORDS}

Decolonization, Literature, Independence, Guyana, Lowe Shinebourne, Poka Laenui

\section{ABSTRACT}

Navigating the journey of decolonization can be daunting, especially without clarity of the processes involved. Hence, literature exploring such processes provides direction for the journey. Additionally, the directions suggested in the literature become more credible whenever a synergistic dialogue arises between diverse authors and different genres of texts. To such effect emerges the compelling conversation between Guyanese Jan Lowe Shinebourne's 1988 novel The Last English Plantation and Hawaiian Poka Laenui's essay "Processes of Decolonization." This paper shows that when read side-by-side, Lowe Shinebourne's novel set in the 1950s and Laenui's essay advance the scholarship on how to measure the extent and quality of decolonization that has been accomplished by an entity. To illustrate this, this study observes the arrangement of images of four young women characters as they operate in Lowe Shinebourne's landscape, and highlights the function of these four characters to the novel's protagonist. The protagonist is interpreted as the schema - individual or country, through which the four characters derive meaning. These meanings are explored through perceived links between the four characters' functions and Laenui's five phases of decolonization, where the characters appear to have the capacity to function as facilitators or representations of the phases. Ultimately, the study finds that Lowe Shinebourne's fiction strengthens Laenui's proposal, and in turn his foundational theoretical work illuminates the processes that her novel investigates. Therefore, it can be concluded that if the processes of decolonization largely function in the way that the dialogue between these two texts confirms, Laenui's template for measuring progress in decolonization can be applied to the understanding of other fictions of decolonization. Further, if this application continues to see consistently agreeable outcomes, it might be concluded that this template may be an effective instrument that can be formally implemented in assessing an individual or country's progress in decolonization.

\section{Introduction}

Newly independent countries must evaluate their progress in decolonization. This is especially true for countries on the cusp of major change within their first century of independence. Before or while moving towards new large-scale economic, social or political events, it would be worthwhile for a former colony to understand and articulate their progress on their journey of decolonization, for as Hawaii's Poka Laenui (2000) says: "The process of colonization and decolonization deserves closer consideration in attempting to refashion societies. Otherwise, we may find that we are merely entrenching ourselves deeper in the systems, values, and controls put in place by the colonizer" (p. 159).

Considering the quality and quantity of literature on decolonization emerging in the last fifty years, articulating progress in decolonization should be intrinsic and manageable for individuals as well as countries. Raymond Betts (2013) notes that in the early days of decolonization, "As the colonies broke away, scholars amassed considerable literature on the subject. In the 1970s,

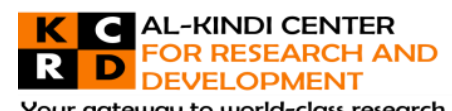

Your gateway to world-class research

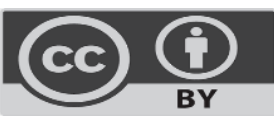

Published by Al-Kindi Center for Research and Development. Copyright (c) the author(s). This open access article is distributed under a Creative Commons Attribution (CC-BY) 4.0 license 
more than two dozen studies in English carried the word 'decolonization' in their title" (p. 27). To qualify Betts' statement here and attempt even a comprehensive list of scholars of postcolonial studies would fail to do justice to the incredible global thesis achieved by the many meticulous and eloquent voices in the field. However, as Jan C. Jansen and Jürgen Osterhammel (2017) say: "an elaborate postcolonial theory of decolonization is yet to come" (p. 170). Furthermore, as we advance into the twenty-first century, where it might be seen that intensive technological progress and globalization more decisively intersect with neocolonial momentum, theories of decolonization must continue to advance just as intensively. Most importantly, the application of these theories must just as decisively provide a means to measure the degree and quality of progress made on the journey of decolonization. To this end, we must constantly be looking for old but unearthed connections, as well as new and structured conversations that arise among voices in the field. We should consider going in search of synergistic cross-genre and cross-cultural dialogues that may advance our methods of assessing our personal and national narratives of decolonization.

To exemplify such a search, this paper examines the synergistic conversation that arises out of a side-by-side reading of an essay composed based on observations gathered by Hawaiian researcher Poka Laenui (also known as Hayden F. Burgess) and a novel set in a third-world landscape written by Guyanese-born writer Jan Lowe Shinebourne. Together, Laenui's "Processes of Decolonization" and Lowe Shinebourne's The Last English Plantation provide a template for measuring an individual or country's phase and quality of decolonization.

\section{The Role of Fiction in the Journey of Decolonization}

One little-known country that gained independence just about half a century ago and recently emerged in international headlines for impending large-scale socio-economic events is Guyana. Guyana, formerly called British Guiana, gained independence in 1966 and became a republic in 1970. A century has not elapsed since Guyana's pre-independence struggles, and the story of the fall of King Sugar on the landscape is not yet concluded. Further, it is also possible that the population has not fully assessed whether they have sufficiently progressed through the phases of decolonization. Yet, a new expansive story of oil discovery, with its own set of processes, has overlapped and begun on the landscape. Andrew Fawthrop (2021) reports: "Oil exploration in Guyana is set for a bumper year in 2021, with 16 new wells expected to be developed in the emerging offshore region" (para. 1). Amidst such major changes within the last century, the country as a whole, its individual citizens, as well as other countries undergoing similar experiences, may find it a rewarding reflection to situate their futures in relation to their current states on their journeys of decolonization.

In broad terms, "What we normally characterize as decolonization was the collapse of colonial empires and the creation of new nation-states across what came to be known in the decades following World War II as the Third World" (Kennedy, 2016, p. 5). In a general summary, Dane Kennedy charts that the first phase of decolonization occurred in the late 1940s and progressed in waves through to its third wave in the 1970s (pp. 23, 47). He relates that, for the most part, the thirty years after World War II saw the rapid cessation of colonial rule over more than a hundred "new nation-states across the third world" (p. 46). Yet, all this is not as tidy as any succinct definition would imply, for as Jansen and Osterhammel (2017) remark, decolonization really does have, "A plethora of meanings, ambiguities, conflicting memories, and competing narratives..." (p. viii) and most notably, decolonization "designates a specific world-historical moment, yet it also stands for a many-faceted process that played out in each region and country shaking off colonial rule" (p. 1). The emphasis must be seen on the word 'each,' for ultimately, each region, each country, each individual is the keeper and evaluator of their narrative of decolonization. Therefore, consistently expanding narratives such as studies and dialogues on decolonization, as well as fiction from newly independent countries are crucial to the understanding and assertion of self to the world. Jansen and Osterhammel seem to agree when they say that "Decolonization was not just something that happened in the realm of politics and economics; it also took place in the world of ideas and discourses" (p. 156).

Literature has long been a means of holding space and asserting power and the Global North has long held such space. In Culture and Imperialism, Edward Said (1994) confirms the role of fiction in expanding and asserting imperial power:

Since narrative plays such a remarkable part in the imperial quest, it is therefore not surprising that France and (especially) England have an unbroken tradition of novel-writing, unparalleled elsewhere. America began as an empire during the nineteenth century, but it was in the second half of the twentieth, after the decolonization of the British and French empires, that it directly followed its two great predecessors. (pp. 17-18)

It follows then, that if fiction possessed the capacity to further the imperial cause, fiction could also propel decolonization.

This is why the Global South, former colonies, the third world, decolonizing nations, newly independent countries such as Guyana, must write. These nations must write, and their own population and the rest of the world must pay attention to and search for the transformative elements in what they write. I endorse here the vigour of Hélène Cixous's language and idea that a woman must write before she is to recover the space taken from her. Cixous (1997) says: 
Woman must write her self: must write about women and bring women to writing, from which they have been driven away as violently as from their bodies.... Woman must put herself into the text - as into the world and into history - by her own movement. (p. 320)

In saying this, Cixous legitimizes the link between literature and the reclaiming of power, and her paradigm can be applied to the experiences of other underprivileged groups. To transpose Cixous's language to the issue of decolonization then, the Global South must constantly put themselves "into the text," "into the world and into history" and they must do so by nobody else's "movement" but their own. It is imperative that they do so, because their stories, these narratives of decolonization, in Said's (1994) words:

...become the method colonized people use to assert their own identity and the existence of their own history. The main battle in imperialism is over land, of course; but when it came to who owned the land, who had the right to settle and work on it, who kept it going, who won it back, and who now plans its future-these issues were reflected, contested, and even for a time decided in narrative. As one critic has suggested, nations themselves are narrations. (p. 10)

In short, a country's literature bears a relationship to how that country decolonizes. This is why these countries must write unfettered, as many indeed have been doing. As Silvio Torres-Saillant (2013), who refers to "the close relationship between power and literary hegemony" (p. 317) says:

Perhaps nothing sheds so much light on the role of power in literary relations as the rise of Third World literatures after World War II. The literatures of those formerly subject peoples have come into view precisely to the extent to which they have challenged the validity of Western hegemony. (p. 316)

So these peoples have been writing and must continue to do so. And when they write, we must read. We must read and apply their best and most relevant ideas to our individual or national journeys of decolonization.

One criterion of classifying a narrative of decolonization, is to gather the sense that the text is working its way through the initial stage of the physical transition of power from the colonizer to the former subjects by expressing the ensuing psycho-social, socioeconomic and political dynamics involved during this transitional period. In Lowe Shinebourne's 1988 novel, the protagonist's father, Cyrus Lehall, is one of the voices that identifies an initial physical marker of decolonization on the land when he says: "'One day, our own government will be running estate. I not worried... whether the overseer will go or stay. I know this going be the last English plantation...'" (p. 13). His statement serves as a marker for the period between the phasing out of the physical colonial presence and the country's Flag Independence. In this regard, The Last English Plantation qualifies as a narrative of decolonization.

Immediately, the title of the novel conveys the transition to which Cyrus draws our attention - change in the role of King Sugar, the phasing out of large scale manual labour, the withdrawal of the physical colonial presence from the landscape and movements towards defining a Guyanese identity. Through its protagonist, June Lehall, the novel grapples with the period of the 1950s and beyond, which was particularly tumultuous since so many social, economic and political variables were operating at once on the Guyanese landscape. During this time, the country was undergoing many experiences: defining their sense of nationalism; threading the path to full independence; reinterpreting their old relationship with the British; working to understand their new relationships among the different racial groups and social classes, amidst the many violent clashes of selfhood and nationhood; and coping with the effects of how their local movements were situated in world politics. ${ }^{2}$ The Last English Plantation traverses this crucial transitional period in Guyanese history, allowing its protagonist to function as a schema or framework or self for negotiating processes associated with decolonization.

It appears justifiable to read the novel's protagonist, June, as the representation of the individual citizen's or country's journey of decolonization in the years leading up to and following Guyana's independence because Lowe Shinebourne's characters, more so the women, appear especially crafted to express major variables and processes occurring on the Guyanese landscape in the 1950s and thereafter. In elaborating on her use of images of women in The Last English Plantation, Lowe Shinebourne explains how women characters like Nani Dharamadai, for instance, were carefully crafted to represent some aspect of daily life in her society: "In our village, there were several childless Indian women willing to adopt me as a surrogate daughter. One, whom I called Auntie Bhan....She is the model for Nani Dharamdai Misir..." (as cited in Lee-Loy, 2008, p. 40). It is obvious then that Lowe Shinebourne takes great care with the messages that her older women characters present, care which is also evidently given to the creation of her younger women characters. Thus, it is justifiable and easy to perceive that independently, communally and schematically, young women like the protagonist and Annie and Sarah Beardsley, Lavender Jones, Mariam Mootoo all carry messages in the

2 For a comprehensive presentation of conditions in this transitional period in Guyana's history, see Winston McGowan's Chapter 58: The Origins and Growth of Nationalism in British Guiana, 1880 - 1961 in A Survey of Guyanese History, (Guyenterprise, 2018), pp. 364-381. 
narrative and can represent the forces in the text that negotiate the complex inheritance of colonization and decolonization on their landscape. If read using a schematic model, where the protagonist June is seen as the Self or the cognitive framework through which the dynamics of decolonization in the novel are negotiated, then it becomes interesting to analyse Annie, Sarah, Lavender and Mariam's functions as processes occurring within June, who can be interpreted as individual Guyanese identities or the Guyanese society as a whole. To further justify reading the novel this way, it must be underlined that these four characters have weak operational strength in the narrative without their connections to June. It is mostly June whose interactions with them elevates the meaning of their actions. If we ascribe each character an appellation, the interactions become more illuminating. We see June as she tries to cope with the image of the Silent Fading Annie, haggle with the image of the Ambivalent Commander Sarah, empathize with the Volcanic Victim Lavender and understand the Proactive Martyr Mariam. We then see that the narrative succeeds because June is always trying to 'process' these characters. Further, these four characters can each be closely linked with one or more aspects of decolonization. This arrangement and function of characters therefore validate the reading of Annie, Sarah, Lavender and Mariam as representative of processes flowing through and operating within June.

Interestingly, the functions of these four young women-characters from this novel published in 1988, appear to align with several aspects of the phases which Laenui (2000) outlines in his essay "Processes of Decolonization." Even more interestingly, is the fact that this welcome alignment appears to have come about inadvertently. Laenui, who though in a different geographical location and different cultural background may have been working on these similar ideas around the same time as Lowe Shinebourne, pinpoints a slightly later date, the mid-1990s, as the timeline for the configuration of the step-wise layout of his essay. He explains that the list of processes was modelled and built on the oral work of Professor Virgilio Enriques of the Philippines, with whom he conversed in the mid-1990s (p. 150). Enriques theorized that there are five processes of colonization which he saw as: (1) denial and withdrawal, (2) destruction/eradication, (3) denigration/belittlement/insult (4) surface accommodation/tokenism, and (5) transformation/exploitation (pp. 150-152). Thereafter, to compose his list of the five processes of decolonization in parallel fashion to Enriques' list, Laenui embarked on: examining "others' experiences as they move from one phase of decolonization to the next" (p. 150); analyzing his personal experiences on the Hawaiian landscape; interpreting Hawaii's social dynamics; researching occurrences in the Pacific region; and, observing global occurrences. He then arrived at the five phases of decolonization, which he says are distinct but not necessarily linear, isolated or absolute. They are (1) rediscovery and recovery, (2) mourning, (3) dreaming, (4) commitment, and (5) action (pp. 150-152). These phases provide an interesting template with which an individual and a population can measure their progress in decolonization.

Though this means of measurement is constructed primarily of Laenui's experiences in Hawaii, whose history is in many ways different from Guyana's, its validity as a measurement that can be applicable to Guyanese progress is made evident by the scale's unexpected alignment with elements of fiction emerging from the postcolonial Guyanese landscape. Closer examination of The Last English Plantation's structural composition in conveying the theme of decolonization reveals that Lowe Shinebourne's Annie and Sarah Beardsley largely function as catalysts to propel June's phase one of rediscovery and recovery, while Lavender Jones functions as the channel for June's phase two of mourning and Mariam Mootoo generally activates June's experience of phases three, four and five, which are dreaming, commitment and action.

\section{How Annie and Sarah Beardsley Act as Catalysts in June's Phase of Rediscovery and Recovery}

The sisters Annie and Sarah, daughters of Overseer Beardsley, can be seen as a pair of catalysts that visibly and audibly activate June's first phase of decolonization. The processes of rediscovery and recovery are propelled to fuller exploration when June reluctantly enters the overseer's quarters and is forced to interact with the sisters. June comes face-to-face with what Laenui depicts as the entryway between the colonial past and the decolonized future. It is a phase that arrives with propulsion "...out of curiosity or desperation, by accident or coincidence, to escape, or because of fate" (p. 152). June's journey is probably propelled by all of these conditions, though desperation and curiosity may be the dominant factors - desperation to escape her father's haranguing about how it was their responsibility to go and comfort little Annie in her time of illness, and curiosity to understand why of all people, she, June, was chosen to do so. At this point of her journey, it is interesting to see how June's fictional experience aligns with Laenui's real world description of his own journey.

Laenui explains that his personal introduction to the first phase of decolonization occurred when he was a volunteer member of the US military. While in the library on the military base, he happened upon a book by Queen Lili'uokalani that chronicles the colonial history of the Hawaiian nation. After reading this book, Laenui experienced a point of no return in his personal search for historical answers that were not previously a part of his worldview (p. 152). What Laenui describes here appears to be a movement from a state of powerless innocence or ignorance and passivity to a state of awareness, recovery and pro-action. Lowe Shinebourne's work appears to agree with this idea, that the journey of decolonization must begin with an inciting incident which, once activated, cannot be denied. Evidence of her agreement comes in the opening of her novel with the chapter titled "The Invitation," in which Beardsley comes to ask Cyrus if he would send June to play with his sick daughter Annie. The invitation functions as a similar device to Laenui's history book. It is a call to action. When her father accepts the invitation and June reluctantly goes to the European quarters, she, like Laenui, is transported to an experience of no return, in which the previously-colonized 
engages directly with the old colonial systems which they inherited and adapted and must begin investigating more closely if they are to thread the path of full or substantial decolonization. By reluctantly stepping foot in Overseer Beardsley's gated compound, June assumes some power in opening up her own dialogue with decolonization. She allows herself to stay on the path to rediscovery and recovery, a phase that is sometimes uncomfortable.

Alluding to this discomfort, Laenui states that in phase one, people are constantly exposed to colonial reminders that activate their feelings of inferiority for their own "historical cultural/social background[s]" and experiences (p. 152). Though these backgrounds to which Laenui refers would be different from Lowe Shinebourne's landscape, June's experiences still appear to confirm Laenui's conclusion, as when she arrives in the European compound, "The overseer's quarters were guarded strictly. No one could enter without a security check" (p. 20) and she is not allowed to go through the front door; instead she is instructed to take the kitchen door (p. 23). In Great Houses or Compound Houses, being directed to the kitchen door or side door is a common signal of servant status. Though she is needed for her local psycho-social knowledge and the support that she can provide the overseer's daughter, June's competence and potential friendship are not perceived as gifts worthy of a position of power or even of mutual exchange; rather, she appears reduced to being tolerated as she tiptoes around in a realm in which she is a very minute entity indeed. In this realm, this colonial 'house,' June must grow from that minute entity, that mode of service, into an independent being; she must leave behind the functions and title of colonized and create other means of self-definition.

Having a physical presence in close proximity to the colonizer, sets June on a path where she makes a thoughtful journey of decolonization. On this first phase of her journey, she encounters the Beardsley sisters who appear to represent two aspects of the aftermath of colonization on the Guyanese landscape. This interpretation is justified when we see that both sisters come from the same 'origin' - they have the same colour of hair and eyes, but different complexions and personalities. This validates the idea that they can be seen as different, sometimes even warring dimensions of colonization. The Silent Fading Annie Beardsley appears to function as history and elements of colonization that were being substantially eroded during the transitional years when the colonial presence was gradually physically withdrawing, while The Ambivalent Commander Sarah Beardsley functions as those colonial elements that survived on the local landscape and attempted to retain a robust presence in the society, but sometimes with dual intention and function. Together this pair of characters or functions works as a catalyst in June's cognitive domain or her journey to help her locate, re-shape and define her feelings. By engaging with these two functions, June manages to rediscover and recover and create elements of her decolonized identity and cross over from phase one of her journey.

Laenui frames "Rediscovery and Recovery" as the foundational phase for the overarching journey of decolonization (pp. 152-153). It stands to reason that in this phase, the individual or country looks backward to look forward and then activates ownership of thought and action. The novel's Annie can therefore be seen as the catalyst propelling June into this phase, since in June's schema of decolonization, Annie acts as the phasing out of the old colonial order that cannot survive on the landscape. Yet, Annie's need for June demonstrates that there still exists a relationship between her and the protagonist. For some reason, it appears as if the protagonist must develop an awareness of this relationship before she can move forward. Lowe Shinebourne allows her protagonist to take up the challenge.

At the beginning of the narrative, June refuses to face Annie. Perhaps this can be interpreted as denial in facing her country's colonial history head-on. When Annie first appears in the text, she is standing in a doorway - a liminal space -possessing "very white hair" and a lifeless face which June "could only compare...to very old, sick people," her "unnatural" whiteness giving June "a fright" (p. 23). In fact, Annie's leukaemia, the pathological decrease of white blood cells, appears as a symbol of the fading away of the white colonial power on the Guyanese landscape. Because of the growing cosmopolitan population and new social and cultural dynamics, Annie cannot survive on the postcolonial landscape with only her earlier functions. She can therefore be interpreted as older colonial processes such as importation of workers, supervision of labour, plantation yields, events that the young generations may forget. Without June's awareness of these, their historical dynamics - both sordid and ambivalent, will fade away in time. Interestingly, her sister Sarah does not want Annie to be understood or remembered. She minimizes Annie's role and distracts June by demanding full attention; she says: "She [Annie] can't play! She's not well. Play with me" (p. 25). But if June does not rediscover her history, part of which is represented by Annie, then her journey of decolonization may only be limited to phase one.

So though Annie is the defunct vestiges of colonization, June facilitates her and advances in her own personal growth because she does so. She moves from strongly opposing visiting Annie, to then befriending her (pp. 15-17), to trying hard to play with and understand her condition (pp. 25-29), to attempting to protect her (p. 83). These acts can be read as June coming into awareness and a sensitivity when dealing with colonial issues of the past, an existence from which she is detached but still connected. She loses her antagonistic stance towards it and comes to accept it as a part of the self that must be carefully studied and sensitively handled. June notices that with every interaction, Annie becomes more and more detached from her environment, losing physical control and influence over her functions: June wonders whether Annie could feel herself being bitten by ants ( $p$. 24); she notes that Annie doesn't "look around the school" and remains detached from her experiences there (p. 61); she hears Annie making no 
attempt to answer her name at roll call (p. 69) and that she nearly vomits (p. 83). Annie, pale, wordless, detached but present, is the retreating shadow of colonialism. Yet, her presence, though diminishing, is haunting. Long after the last page is turned, it is Annie's spectre-like existence that haunts the imagination. June sees in Annie something to be startled by but something which she must investigate in order to understand her own identity and role. Annie's representative interlocking function between colonization and decolonization is the mechanism that causes June, the daughter of a freed labourer, to cross over into spaces once occupied by the colonizer, where she experiences the blurred lines and role reversals between the colonizer and colonized, and begins to re-shape her own path. In essence, Annie catalyses June's engagement with the process of rediscovering her history and negotiating her reaction to it.

Unlike pale fading Annie however, Sarah still very much belongs to the landscape in a robust and often confrontational manner. She performs a dual function. She is the side of colonization that evokes shame and inferiority and defensiveness in the brain of the colonized, and she also represents the aspects of the colonial self that are so intricately interwoven in the local way of life that she cannot be gotten rid of as easily. When June first sees her, unlike Annie who is standing in a doorway, Sarah is very much a vivid part of her physical environment, leaning against a short coconut tree and shouting and laughing with "lively eyes" and "skin red from the sun" (p. 24). Further, as Sarah, is sometimes at odds with Annie because she wants June to focus on her, not Annie, June has to choose how to navigate equivalent attention to the narrative of the colonial past and the current narrative of the colonial present. By engaging with Annie, June rediscovers the understanding of the importance of the knowledge of one's history and by engaging with Sarah, she recovers the validity of her current local life.

Laenui observes that "This phase of rediscovering one's history and recovering one's culture, language, identity, and so on is fundamental to the movement for decolonization. It forms the basis for the steps to follow" (p. 153). On this observation, Lowe Shinebourne's novel continues to agree, as the protagonist's first and subsequent interactions with Sarah Beardsley comprise Sarah's linguistic, social and cultural criticism of June. They argue over mites and insects and children's games and later, over more important topics. On the day that they meet, Sarah criticises June's localised pronunciation of the red mite: "It's not bet-ruche, it's bête-rouge. It's French and it means red beast. And we don't have ants and bête-rouge on our grass..." (p. 24). It is easy to see that Sarah's punctilious air about the red mites is not so much about the red mites as it is about the colonial presence inhabiting a decolonizing society and creating ongoing conflict with it. This presence uses colonial performatives to judge the local cosmopolitan worldview. It is one of the vestiges of colonization that the formerly colonized must navigate. So June finds ways to present decolonizing arguments both to herself and to Sarah. She presents an argument to herself mulling that instead of bêterouge, "People in New Dam said 'bete-ruche' and as long as they thought it was alright, it was alright" (p. 24). To Sarah, she validates local ways in which things are named and performed, for example, when she says that she'll play catch and produces five bricks, and Sarah laughs and says "'That's Jacks. In England you use a rubber ball and five metal pieces,'" June responds, "'Well this is not England and we use bricks'" (p. 25). Ultimately, June consistently recovers the meaning of her personal existence on her landscape through successfully haggling with Sarah over everything: "The child was going to find one reason or another to criticise her. She was trying to get the advantage over her. June was not going to let her do it" (pp. 24-25).

But though June resists Sarah's dictates, she never becomes violent or aggressive; instead, she both accommodates and challenges whatever Sarah suggests so that she can adapt as much or as little of Sarah's influence as is suited to her, June's, developing worldview. An example of this can be seen when Sarah wants to ride June's bike. We might interpret the bike as the impending freed subject's independence, upon which the old colonizer inadvertently will or still hopes to hold influence. June seems to understand the controversial implications of not letting Sarah ride the bike - for after all, in the complicated dual manner of viewing one's colonial heritage, June's very existence on the sugar plantations is owed to colonization, the arrival of her ancestors to the plantations and the intermarriage of racial groups - so she strikes a balance in the use of the bike. She lets Sarah hop on, but June herself continues to push Sarah instead of letting her ride freely (p. 28), thereby meeting and successfully managing the confrontations of the inherited ambivalent elements of colonization in her life. She steers these elements in the direction that she wants them to go, without allowing herself to be controlled by them.

Through her interactions with the processes represented by Annie and Sarah, June comes to negotiate her complicated relationship with the colonizer, both defending her own way of life and wondering at her own transitory role in putting them "behind the fence" (p. 30). By consciously engaging with these aspects of phase one, June decisively advances in her journey of decolonization.

\section{How Lavender Jones Functions as the Channel for the June's Phase of Mourning}

Both Laenui and Lowe Shinebourne place significant weight on Mourning as a process of decolonization. For Laenui, Mourning is phase two of decolonization, "A natural outgrowth of the first phase ... a time when a people are able to lament their victimization. ...an essential phase of healing" and a means of hastening phase one (p. 154). Yet, though phase two is essential, both writers carefully illustrate that all mourning is not created equal. There are healthy expressions of mourning, such as Laenui's example of 
Hawaii's 1993 public "symbolic mourning of the loss" of their nation (p. 154). But, the mourning stage can become unhealthy if not monitored. Laenui describes:

This phase may also be expressed in great anger lashing out at all symbols of the colonizer. A sense of justified violence, either in words or in actions, can lull some into remaining in this phase, milking every advantage of the innocence of one's victimization. The abuse of the mourning phase can turn into an attempt to entrench the colonization in order to continue the mourning, the anger, the hatred, and the division among people. Some are happy to go no further than mourning, finding sufficient satisfaction in long-term grumbling. People can be "stuck in the awfulizing" of their status as victims. Some build careers on it. (pp. 154-155)

When the individual or group leans too heavily to the unhealthy side of the mourning spectrum, the outcomes of their stories are detrimental or ambivalent. Lowe Shinebourne's character Lavender Jones appears to confirm Laenui's observations, as Lavender's actions can be classified on a spectrum of mourning, from reasonably healthy to quite unhealthy. Fortunately, in the end Lavender, and by extension June and June's country, barely manage to elude being trapped in phase two.

When Lavender first appears in the novel, she is aware of the dividing lines of social class and displays a doleful but matter-offact attitude about her status. She walks to school from another village, admires June's bike and admits to having to wait to buy her books second-hand (p. 57). At this point, she negotiates her lack of amenities with the practical approach of hopping on the carrier on June's bike to be towed (pp. 57-58). But later on when her clothes are judged as cheap and ill-fitting and her hair is perceived as styled in a 'lower' class fashion, "not straightened like Paula Duncan's and Louise Sampson's..." (p. 82), Lavender's feelings of inferiority are activated, and she struggles to engage with the world without interpreting everything that happens to her through the lens of the dividing rungs of power and class. To Lavender, Paula and Louise's hair and clothes are, to retain Laenui's expression, "symbols of the colonizer." Everywhere she looks, she can identify these symbols and moves steadily towards the unhealthy end of the spectrum of mourning, observing and criticising all the school children who show any inkling of wealth or social dominance, perceiving them as colonizers. She even judges them based on what she hears about their parents, such as when she tells June to steer clear from Peter Johnson because she heard that his father, Overseer Johnson, liked to rape women (p. 83), or when she expresses disdain for black and brown children who travel on the plantation bus because their parents, in the transitional period leading up to independence, had stepped into white overseer shoes (pp. 83-84). In all these ways, Lavender carries the weight of the colonial past into her everyday routine and struggles to move forward and reconcile her current experiences to a new and decolonized future.

This worldview escalates her dis-ease in her society, so that Lavender grows physically violent and feels justified in doing so. When the boys continue to ridicule her appearance, she professes that she "would give them all a good kick" (p. 82) and later gets into a vigourous fist fight with them (p. 114). By ascribing to herself a pseudo-power in physical aggression, Lavender tries to work her way out of a wounded state. But her psychological injuries being replayed on a loop, force her to become more alienated so that she destroys anything potentially good that she can attain, such as her connection with June. She becomes violent, lashing out at June, letting her know that she, Lavender, would not help her get her bicycle because she wasn't June's "slave" (p. 84) and because everyone was "high and mighty" (p. 85). In the end, Lavender cuffing and raining blows on June "was hysterical, screaming, shouting tears streaming down her face" (p. 85). At this point, Lavender can be seen as abusing the mourning phase. There is no reason for her to interpret June's request to help her retrieve her bicycle from under a stack of collapsed bikes as something colonizing or negative. At this point, Lavender unnecessarily retreats deeper into the victim-mentality, "awfulizing," to use Laenui's expression, everything. Her withdrawals take the most painful forms, destroying herself and her relationships: "Lavender turned and ran away. She disappeared behind the auditorium. June followed her. When she reached the gate she looked for Lavender and saw her under the low bottomhouse of the auditorium" (p. 85). Later, when Lavender gets into the violent fight with the boys and both sides rain blows on each other, Lavender once again runs away, this time out of the school compound and into town (p. 114). Lavender never truly reconciles herself with her classmates, even though deep down what she really wants is to be accepted and belong.

In the end, her education perishes and she gives up her current school to wait for placement at another school or to be homeschooled. While she waits, she does chores in a sergeant's household (p. 164). Ultimately, she is 'banished' from the educational landscape. One even gets the sense that her future schooling will become formless or non-existent. Still, it can be interpreted that Lavender though appearing as a Volcanic Victim, narrowly escapes achieving total self-destruction. She eventually manages to weigh situations more objectively, rather than only through her victim-assertive status. This can be seen when in the inquiry at the end, she confirms that Sarah indeed spoke distastefully to the locals. But Lavender, also learns to see the complexity of her landscape rather than view it in the old simplistic polarised manner: "...she added that children who passed by the overseer's house also abused Sarah when she was only standing at the fence watching them go home from school" (p. 173). And in the final sentence in that chapter there is some small, though ambiguous measure of Lavender's self-assurance: "Lavender disappeared behind the station to help her father" (p. 174). 
Now the analysis above may confirm that it is entirely possible to read Lavender as an independent character who in fact channels the process of mourning but without any established connection to the protagonist. But there is enough evidence to establish that Lavender can be interpreted as a process directly experienced by June, as Lowe Shinebourne allows the protagonist herself contemplate this. The end of Chapter 8 - "A Failure", is particularly significant in supporting the idea of seeing Lavender as one aspect of June or June's society. After a fistfight and a squabble between them, June cycles away and:

She thought about Lavender huddled like a dog under the bottomhouse, and saw herself [June's self] small and weak against the strong breeze, dwarfed by the landscape and distance around her, struggling towards home, and felt that somewhere in this first day at the new school there had been a failure, something had gone wrong that would never be right again. (p. 86)

Lavender's victim shape is a painful one to behold and is also June's own shape, as June clearly establishes that interlocking experience. Lavender is the part of the self that struggles hard to adapt but is often at dis-ease with its society. She falls into a repetitive pattern of mourning, not suitably monitored. She represents the part of the postcolonial self or society that struggles to negotiate its pain and shame and prefers to engage with one of two extremes - open aggression or withdrawal. But for Lavender's above-mentioned measure of improved self-regulation and self-assurance in the penultimate chapter, we may not have assumed that June or June's country successfully negotiates phase two of the decolonizing process.

\section{How Mariam Mootoo Activates June's Phases of Dreaming, Commitment and Action}

Laenui describes and elaborates individually on phases, three, four and five - Dreaming, Commitment and Action, but he also establishes their relationship among each other. He equates the Dreaming phase with the period of fetal development ( $p$. 155) and highlights that "It can be difficult to distinguish between an early termination of the dreaming phase and the start of commitment phase" (p. 157). He then emphasizes that the Action phase is dependent on the Commitment phase (p. 158). As such, for the purpose of this essay, phases three, four and five can best be perceived as a single but multifaceted and progressive process or mechanism. Most interestingly, in an uncanny alignment with Laenui's suggested connections among these three phases, one single character of Lowe Shinebourne's also appears to cumulatively display qualities of each of these three phases.

The character Mariam Mootoo advances the narrative of decolonization through dreaming, commitment and action as her performances range from operating outside her gender roles to advocating a better quality of living for the plantation labourers. Though she is not a character who physically appears often in the novel, she appears briefly and on the most significant of events - June's first day of high school and on the day of the protest on the estate. The first event marks the start of the individual's, June's, personal journey of independence into her transitional adolescent years, while the second event marks an incident for the country, to signal Guyana's transitional years between the last English plantation and National Independence. For June's journey of decolonization and by extension, the country's journey of decolonization, Mariam Mootoo is the embodiment of phases three, four and five with varying measures of accomplishment at each phase.

Of all the phases, Laenui elevates phase three; dreaming, he says, is the phase "most crucial for decolonization. Here is where the full panorama of possibilities is expressed...which eventually become the flooring for the creation of a new social order" (p. 155). But what does dreaming look like on a newly decolonizing landscape? Surely, it must take on the lifestyles and worldviews of the formerly colonized peoples. As Laenui clarifies: "It is during this phase that colonized people are able to explore their own cultures, experience their own aspirations for their future, and consider their own structures of government and social order to encompass and express their hopes" (p. 155). Undoubtedly, Lowe Shinebourne has inadvertently endorsed Laenui's position on this phase, as she crafts her character Mariam to operate with a sense of ease that many of the other characters are unable to achieve. This ease of self may be linked to the stage of dreaming. Mariam's open acceptance of herself as she is, can be interpreted as one measure of dreaming, dreaming of becoming a people who are less preoccupied with fitting into a European mould and more focused on forging ahead with accepting the cross-cultural and intercultural practices and languages that are organically taking shape through the merging of lifestyles of the various groups of peoples in the country.

This ease of self is demonstrated by several references. Mariam is unashamed of her language, occupation and role - the ultimate expression of freedom and the dream of independence. When she first appears, Mariam is balancing a basket on her head. She comes with the full image of the labourer and farmer, as a Hindi-English-Creolese speaking woman of regal carriage, as one who "had never married and had children like most Indian women" but who treated other people's children as her own" (pp. 52-54). Because she appears not as a mother, or a married woman, the usual trope for women of her time and place, but as a worker of the land and "breadwinner of the family" of sick, crippled and alcoholic men (p. 53), Mariam cuts through gender role barriers to free herself to operate in other ways. June knows her as the woman who bears simple but bonding gifts - "rare and sweet waternuts ...from the creeks and canals where she worked," "roti, pumpkin curry and achar," even money from the little that she has ( $p$. 53). Though it may appear as if her impoverishment and solitariness are the antithesis to dreaming, Mariam is, above all things an embodiment of freedom of spirit and pride of self, regardless of her circumstances. To a large extent, she is mistress of her destiny and it appears as if this is the dream which she extends to her plantation or village, as the next memorable time that we see her, 
she is on the protest's frontlines proclaiming that the villagers should be allowed to remain on their land. As her confederate Boysie had said, "the overseers made them live like animals, as if they were not human. ...[so the] solution was to make the overseers leave Canefields [their village], not the workers, the people who had lived there all their lives" (p. 32). Fleeing to homelessness, while the logies were being bulldozed was not aligned with Mariam's dream for her people. In this moment, she demonstrates commitment to the dream of community independence and self-determination for her people.

But as Laenui explains, where dreaming ends and commitment begins is sometimes tricky to identify. It seems as if the dream to which Mariam visibly shows commitment is cut short, as was the commitment itself because of her people's divided approach to the dream: "Half the people were going to live in villages beyond the plantation. [Even though] They were the ones who had ceased to work for the overseers, who were not being found new homes and had nowhere else to go" (Shinebourne, p. 35). Therefore, any commitment to the dream of retaining their spots on their land that could be put into action could predictably prove unsuccessful or detrimental. As Laenui, emphasizes, dreaming must be allowed to grow and develop, for "So crucial is this phase that it must be allowed to run its full course. If the dreaming is cut short by any action plan or program designed to create a remedy for the issue at a premature stage, the result can prove disastrous" (p. 155), as indeed it does for Mariam's people and Mariam herself.

On a large scale, Mariam's society is divided on the corresponding commitment to action with their dream. An example of this can be seen in the differing views represented by June's parents and Boysie:

Boysie said it was better to fight against the overseers and force them to improve their lives.... She [Lucille] saw fighting the overseers as increasing their difficulties, she did not believe like Boysie that they could win a better life through confrontation. Cyrus believed that they did not need the overseers, but needed only to learn to use their own resources to build their own community.... Beneath their everyday lives this struggle of ideas went on constantly. (p. 99)

In addition to these divided opinions, Mariam and her group are forced to implement a half-formed commitment, which is then compounded by split goals when they are propelled to take the action of the protest. The problem with Mariam and her group's dream is that there isn't enough time for it to mature. In addition, she and her group are divided. For one thing, there is the enacted separate objective of the character named Sookdeo getting revenge by burning the house of Overseer Johnson who is said to have raped Sookdeo's girlfriend (pp. 133-135). Whoever supports Sookdeo's venture causes an escalation for the peaceful protest staged by Boysie and Mariam. Also, when the police disperse the crowd, many of them leave their place in the protest and the industrial action breaks down. Laenui explains, for Commitment to blossom firmly into positive Action, the people should "be ready for commitment to a single direction in which the society must move. This phase will culminate in people combining their voices in a clear statement of their desired direction" (p. 157). In Mariam's story, this fails to happen. Their dreaming is stunted and their commitment is muddled, so their action loses its momentum and purpose.

Moreover, "The action called for in the fifth phase of decolonization is not a reactive but a proactive step taken based on consensus of the people" (Laenui, p. 158). Certainly, the Action in Mariam's movement turns out to be more reactive than proactive. The lines get blurred when Mariam, proactive protester as she is, reactively grabs at Sookdeo's shirt as he rushes up to brandish his cutlass at the police. In the moment that she tries to pull him back to prevent an altercation, she ends up falling to the ground with two others and getting shot and dying instantly (Shinebourne, p. 138). The phase of Dreaming is short-lived as it blurs over into Commitment that is ill-displayed because of a mini-rebellion at cross-purposes, and any pro-Action is dead and buried.

Though Mariam is an empowering fixture in the narrative of decolonisation because her altruistic working class life stands as a mediating factor between the old plantation order and the struggle to phase out the last English plantation, her death stands to represent the immense difficulty in achieving freedom from systematic oppression. Boysie says that they had to fight against the old plantation order:

But look what happened when they did - disaster, panic, confusion, killing, hatred rocking their existence like an earthquake, rocking their ground so hard it would break, destroy the little bit of neighbourliness they did have, that they managed to scrape out of their plantation existence. (p. 156).

For Boysie, Mariam's death comes to represent the threatening and the breaking up of the village, the killing of a community spirit and conscience. Yet, even as Mariam is the proactive aspects of the self and society that are challenged and wiped out and as she becomes a representation of intense waste and loss of human resources, a snuffing out of light by systematic oppression, she represents the sacrifices that are made as a young society comes into being. In the same way that some things die and fall away for an individual to grow and change, so too does The Proactive Martyr Mariam fall away to hopefully pave the way for a less turbulent postcolonial phase. Depressingly Mariam's senseless death seems to support Frantz Fanon's (2004) opening statement 
of his The Wretched of the Earth, that: "National liberation, national reawakening, restoration of the nation to the people or Commonwealth, whatever the name used, whatever the latest expression, decolonization is always a violent event" (p. 1).

Now, like the seemingly self-contained presentation of Lavender, Mariam might at first glance appear to function separately from the protagonist, but a reading of Mariam as a three-phased process of decolonization in June's schema is supported by how closely and secretly June holds Mariam's performative functions to her heart. She shares a meal sitting on the culvert with Mariam, breaks bread, so to speak and never once tells her own mother about it in case she disapproved (Shinebourne, p. 53). Whatever Mariam represents, she belongs in the self's inner meaning and is linked with the purest most genuine aspects of self, growing quietly but not quite ready to blossom into something unique and empowering. It is also significant that Mariam's words of admiration and encouragement to June on her apprehensive journey to her new school (p. 52) come at a time when June is moving towards individuation from her parents and bicycling her way to independence to a school in the town. Mariam's parallel functions of support to the individual and to the community comprise support and endorsement of independence. Perhaps Mariam can function as phases three, four and five in June's schema, processes that were now forming but were far from being fully developed. This idea can be supported by the fact that June appears to grasp the full implications of Mariam's death, but is carried along by the momentum of the funeral and lacks the capacity to articulate the immensely hazy debilitation that she feels. This is seen where she senses the superficiality with which her own mother attends the funeral and takes a dismissive approach to the inherent value of Mariam's life and death (pp. 141-145) but does not register her dismay at her mother's evaluation of things. Perhaps she has not yet reached the age of maturity to engage with these processes completely; still they are events that move her to intense contemplation about the quality of her success or lack thereof, in her quest for independence.

\section{Conclusion}

Lowe Shinebourne uses images of young women in The Last English Plantation by allowing her young pre-adolescent protagonist June to demonstrate a conscious involvement in her journey of decolonization and also by employing other women characters to catalyse and possibly represent June's processes of decolonization. Each of the four women characters examined appear as separate images that reflect their representative processes. Annie Beardsley who appears as the Silent Fading presence represents the old colonial order that has shaped the lives of the colonized in some distant or indirect way. This is the order with which June and, by extension, her Guyanese people, must become sensitised in order to understand aspects of their own identities. Annie's sibling counterpart, Sarah Beardsley appears in the image of the Ambivalent Commander, where she represents the variables and systems of colonization that have not left the landscape but shuttle between controlling and befriending the formerly colonized. Finally, Lavender Jones and Mariam Mootoo, appearing in images of the Volcanic Victim and Proactive Martyr respectively, represent processes of dealing with the inheritance of colonialism and attempting to either live in or shape a new postcolonial society influenced by the processes represented by Annie and Sarah. Perhaps it is appropriate that Mariam should be older than Annie, Sarah and Lavender - the earlier processes, because she is the more mature entity that must bring the combination of processes to fulfilment, regardless of her degree of success in the narrative.

Further examination would also show that the characters as representations of processes can function in more dynamic ways than covered in this paper. Closely studying their functions in this manner would require additional research, which interestingly, would also align with Laenui's noted dynamic conceptualization of the five processes of decolonization. Though the five phases are discussed in this paper in the chronological order presented in his essay, Laenui is careful to say that though the phases are presented distinctly, "Each phase can be experienced at the same time or in various combinations. Like the steps of colonization, these phases of decolonization do not have clear demarcations from one to the next" (p. 152). Further, these phases can "occur in individuals at different times and likewise in general society - some individuals being far ahead or behind in the process" (p. 159); in addition, these same stages can be revisited as necessary (p. 159). This dynamic conceptualization of the five phases leaves way for further research of applying Laenui's theory to other works of fiction and observing how the processes can operate simultaneously, in cyclical interactions, complementarily, and perhaps even at cross-purposes with each other to arrive at a cumulative impact.

On an additional note, further reflection can be done on how Lowe Shinebourne's use of her young women-characters breaks the common Madonna-Whore dichotomy often existing in colonial literatures with patriarchal overtones. In a quiet but effective way, Lowe Shinebourne's female characters, regardless of their sometimes dubious qualities or degrees of success, are hardworking processes that are poised to bring about a message of decolonization. The impetus behind the use of the characters seems, in itself, decolonizing. This set of four women characters breaks free from the singular stock function of a traditionally constructed character, to merge and convey the force of a single dynamic cosmopolitan female protagonist who challenges problematic colonial worldviews, even those of her own mother.

Clearly then, Lowe Shinebourne's novel moves beyond recycled traditional images and familiar patterns and tries to look to the future. This is probably why June's journey lights up in a more discernible pattern when read side-by-side with new theoretical paradigms such Laenui's five processes of decolonization. While Laenui's text theorizes on decolonization independently and Lowe 
Shinebourne's text demonstrates the effects of decolonization independently, together, these texts confirm a more structured template for measuring the quantity and quality of decolonization.

Using Laenui's instrument or scale, I would say that June manages to successfully complete one of the five processes at a good quality. This would be the Rediscovery and Recovery of phase one in which she successfully negotiates the information provided and the functions represented by Annie and Sarah. I would also say that June completes the second of five processes at average quality. This would be the phase in which Lavender represents June's expression of Mourning and does so destructively for the most part, but displays a healthier balance towards the end of the text. We can also say that June completes another of the five stages at a developing but not thoroughly adequate quality. This would be phase three, in which the element of dreaming is substantially but not fully expressed. Finally, the Commitment of phase four might be evaluated as weak and the Action of phase five as very weak as Mariam, the representative of these processes, perishes with a finality. Altogether, in my estimation, the protagonist's progress in the individual phases one through five can be summarized respectively as: good, average, developing, weak and very weak.

This overall analysis might appear to condemn the protagonist's journey of decolonization to an evaluation that barely passes towards the end. But this may be explained by the protagonist representing the initial chaotic decolonizing experiences of the preindependence era. Still, no defence of June's evaluation should be necessary, for as Fanon (2004) says, "At a descriptive level...any decolonization is a success" (p. 2), because decolonization, "infuses a new rhythm, specific to a new generation of men, with a new language and a new humanity. Decolonization is truly the creation of new men" (p. 2). June's rejuvenation is indeed reflected in the final chapter. Initially, to grapple with the vestiges of colonization, she engages with the processes, tries to understand them and evaluate her feelings towards them and ultimately finds her way to a sense of freedom and self-worth. After a fight involving Lavender, June feels ill and decides to ride into town, where she meets a character Merle who tells her that she had "never met anybody with an inferiority complex" like June (Shinebourne, p. 115). But by the end of her story, June is able to arrive at a place of joy and peace on Diwali night, for "The myth absorbed the humiliations of their plantation existence..." (p. 176), with lights, "...every dark spot was searched out and a light placed there; it created a glow on the earth itself" (pp. 176-177) and "...the darkness was completely banished from New Dam and the power of the lights gave a feeling of hope and happiness which she felt the more for the feelings of loss and the dramas of the year" (p. 177). The only way that she is able to arrive at this feeling of harmony with the universe, is because she takes the journey of decolonization, seeing, absorbing, battling all the experiences of and the processes on her landscape.

The main idea proposed in this paper is that countries within their first century of independence must reflect on their progress in decolonization, at both individual and national levels. They must navigate in amounts appropriate to their situations and in ways relevant to their landscape, the phases of decolonization. The main finding confirmed here is that progress in decolonization would be easier to trace and evaluate, if there were a common measure that can be used by individual and country. A large-scale operation always becomes more manageable when the steps are broken down into smaller objectives. As these objectives become more describable, they can become achievable. As such, Poka Laenui's five outlined processes of decolonization are a simultaneously streamlined and flexible template of evaluation. Though his views began as being relevant to his landscape, in time they can be appreciated, adapted, amended or tailor-made and applied to other landscapes and in individual experiences as well.

One question that arises out of the conversation between Lowe Shinebourne's and Laenui's texts is: if processes of decolonization largely function in the way suggested by these authors, how much can the theory therefore, be applied and tested to other fiction? If its application sees further agreeable results, then it may be concluded that Laenui's presentation is a valid template which can be formally implemented in assessing a country's and individual's progress in decolonization. We must continue to observe the workings of this theory in fiction and consider whether those findings will strengthen the proposal of applying the template to real-world settings. Fanon says that "any" decolonization is good. I wish to add that after more than half a century of independence for countries like Guyana, any conscious decolonization is better. This conscious journey and ultimately personal or national assessment can be elevated by using those templates or instruments provided by scholars in the field, scholars such as Laenui, Lowe Shinebourne and others, whose voices are heavily invested in the urgency of mindful and methodical decolonization in the $21^{\text {st }}$ century.

Funding: This research received no external funding.

Conflicts of Interest: The author declares no conflict of interest.

\section{References}

[1] Betts, R. F. (2013). Decolonization A brief history of the word. In E. Bogaerts \& R. Raben (Eds.), Beyond empire and nation: The decolonization of African and Asian societies, 1930s-1970s (pp. 23-37). Brill. https://brill.com/view/title/24125

[2] Cixous, H. (1997). The laugh of the Medusa (K. Cohen \& P. Cohen, Trans., 1976). In M. Eagleton (Ed.), Feminist literary criticism: $A$ Reader (2 ${ }^{\text {nd }}$ Edition, pp. 320-322). Blackwell Publishers.

[3] Fanon, F. (2004). The wretched of the earth (R. Philcox, Trans.). Grove Press. 
[4] Fawthrop, A. (2021, March 17). Guyana is poised for a busy year of offshore oil exploration in 2021. NS Energy. https://www.nsenergybusiness.com/news/industry-news/guyana-oil-exploration-2021/

[5] Jansen, J. C., \& Osterhammel, J. (2017). Decolonization (J. Riemer, Trans.). Princeton University Press.

[6] Kennedy, D. (2016). Decolonization: A very short introduction (Very Short Introductions). Oxford University Press.

[7] Laenui, P. (Hayden F. Burgess). (2000). Processes of decolonization. In Marie Battiste (Ed.), Reclaiming indigenous voice and vision (pp. 150160). UBC Press. Open Library, archive.org.

[8] Lee-Loy, Annie-Marie. (2008). An interview with Janice Lowe Shinebourne. The arts journal: Critical perspectives on contemporary literature, Art \& Culture of Guyana \& the Caribbean, Volume 4, (Numbers 1 and 2) pp. 38-44, EBSCOhost, Database: Caribbean Search.

[9] Lowe Shinebourne, J. (1988). The last English plantation, (Reprinted 2002, 2011). Peepal Tree Press Ltd.

[10] Mc Gowan, W. (2018). Chapter 58: The origins and growth of nationalism in British Guiana, 1880 - 1961. A survey of Guyanese history - A collection of historical essays and articles by a Guyanese scholar. Guyenterprise.

[11] Said, E. W. (1994). Culture and imperialism. Vintage Books, Random House.

[12] Torres-Saillant, S. (2013). Caribbean poetics - Towards an aesthetic of West Indian literature, (2 ${ }^{\text {nd }}$ Ed.) Peepal Tree. 